\title{
EFFECT OF LUPINE AS CHEESE BASE SUBSTITUTION ON TECHNOLOGICAL AND NUTRITIONAL PROPERTIES OF PROCESSED CHEESE ANALOGUE
}

\author{
Rezik Azab Awad ${ }^{1 凶}$, Wafaa Mohammed Salama², Azza Mahmoud Farahat ${ }^{1}$ \\ ${ }^{1}$ Faculty of Agriculture, Food Science Department, Ain Shams University, Shoubra El-Khaima, Cairo, Egypt \\ ${ }^{2}$ Food Technology Research Institute, Agriculture Research Center, Giza, Egypt
}

\begin{abstract}
Background. Healthy foods have been met with marked success in the last two decades. Lupine flours, protein concentrates, and isolates can be applied as a substance for enriching different kinds of food systems such as bakery products, lupine pasta, ice cream, milk substitutes. Imitation processed cheese is made from mixtures of dairy and/or non dairy proteins and fat/oils and is variously labeled analogue, artificial, extruded, synthetic and/or filled. Processed cheese can be formulated using different types of cheese with different degree of maturation, flavorings, emulsifying, salts, and/or several ingredients of non-dairy components. Non-dairy ingredients have been used in processed cheese for many dietary and economic reasons. In this study, lupine paste was used to substitute 25,50,75 and 100\% of cheese in base formula of processed cheese analogue (PCA).

Material and methods. Matured Ras cheese (3 months old) was manufactured using fresh cow milk. Soft cheese curd was manufactured using fresh buffalo skim milk. Emulsifying salts S9s and Unsalted butter were used. Lupine termis paste was prepared by soaking the seeds in tap water for week with changing the water daily, and then boiled in water for $2 \mathrm{hrs,} \mathrm{cooled} \mathrm{and} \mathrm{peeled.} \mathrm{The} \mathrm{peeled} \mathrm{seeds} \mathrm{were} \mathrm{minced,} \mathrm{blended} \mathrm{to} \mathrm{get}$ very fine paste and kept frozen until used.

Results. Lupine paste was used to substitute $25,50,75$ and $100 \%$ of cheese in base formula of processed cheese analogue (PCA). The obtained PCA were analysed when fresh and during storage up to 3 months at 5 $\pm 2^{\circ} \mathrm{C}$ for chemical composition, physical and sensory properties. The histopathological effect of lupines on alloxan diabetic albino rats and nutritional parameters were also investigated. Incorporation of lupine paste in PCA increased the ash and protein contents while meltability and penetration values of resultant products were decreased. Adding lupine in PSA formula had relatively increased the oil index and firmness of products. Feeding rats a balanced diet containing processed cheese enriched with lupine showed marked improvements in islets structure and lowered blood glucose compared to rats fed on basil diet (negative group). Springiness was greatly reduced with increasing the added ratio of lupine in the formula of cheese. All processed cheese produced were sensory acceptable but an overall acceptability was lowered by incorporating lupine in PCA formula. Body and texture score of PCA was the mostly affected by increasing lupine ratio in formula without significant difference up to $50 \%$ substitution of cheese base.
\end{abstract}

Key words: processed cheese, analogue, lupine, histology, textural profile, nutrition 


\section{INTRODUCTION}

Healthy foods have been met with marked success in the last two decades. These healthy foods termed "functional foods" are growing rapidly all over the world due to the increased awareness of the consumers on the impact of food on health [Stoon 2002]. Imitation processed cheese is made from mixtures of dairy and/or non dairy proteins and fat/oils and is variously labeled analogue, artificial, extruded, synthetic and/or filled. Processed cheese can be formulated using different types of cheese with different degree of maturation, flavorings, emulsifying, salts, several ingredients, by-product in dairy factories and non dairy components [Caric and Kalab 1993]. Non-dairy ingredients have been used in processed cheese for many dietary and economic reasons. El-Neshawy et al. [1988] manufactured processed cheese of high protein content from blends of Cheddar cheese, whey protein concentrate (WPC), soya bean protein concentrate (SPC) and chick pea flour (CPF). Hussein et al. [2005] studied the quality and acceptability of processed cheese spreads made from total milk protein and casein co-precipitate. Awad and Salama [2010 a] used egg to replace soft cheese in the manufacture of processed cheese spreads.

Lupinus termis is perennial cultivated herb belonging to the family fabaceae. It is cultivated in Mediterranean region and Egypt for its edible seeds [Tackholm 1974]. Its seeds so much consumed raw as salted lupines after being de-better by leaching out the alkaloids by soaking the whole seeds in several batches of water over a number of days. Lupinus termis is one of the rich plants by alkaloid, amino acids, carbohydrates and proteins with moderate gelatin properties compared to soy proteins [Wäsche et al. 2001]. Lupine is a good source of nutrients, not only proteins but lipids, dietary fiber, minerals and vitamins [Martínez-Villaluenga et al. 2006, Torres et al. 2005]. Lupines contain phytochemicals with antioxidant capacity, such as polyphenols, mainly tannins and flavonids [Oomah et al. 2006]. Interest in lupine production is increasing, due to its potential as a source of protein, or for pharmaceutical purposes due to the high alkaloid content, as a natural component [Gaultier et al. 2003, Smart et al. 2003, James et al. 2004]. The high protein content $25-40 \%$ [Erickson 1985] could be used products, such as pastries, breads, chips and milk substitutes Lupine flours, protein concentrates, and isolates can be applied as a substance for enriching different kinds of food systems such as bakery products, lupine pasta, ice cream, milk substitutes and sausages [Wasche et al. 2001] and also be a main food component when animal proteins are eliminated. No studies have been published on the use of lupine in processed cheese. Therefore, the objective of the present study was to investigate the effects of lupine terms on the properties of processed cheese analogues. Changes in histopathological of pancreas in alloxan induced diabetic rats, as well as the blood sugar and feed conversion ratio were also examined.

\section{MATERIAL AND METHODS}

\section{Materials}

Ras cheese was manufactured using fresh cow's milk as the procedure of Hofi et al. [1970] and ripened for 3 months at ripening room. Soft cheese curd was manufactured using fresh buffalo skim milk obtained from High Institute of Agriculture Cooperation, Shoubra Khima, Cairo, Egypt. Commercial JOHA emulsifying salts S9s and NO were obtained from BK-Ladenburg corp., Gmbh, Germany. Unsalted butter was obtained from Dina farm, Sadat city. Seeds of $L-T e r-$ mis were purchased from the local market. Alloxan monohydrate ( $2 \%$ solution) was used as physiological saline and injected as a single dose of $110 \mathrm{mg} / \mathrm{kg}$ body weight subcutaneously within 50-75 seconds.

Preparation of lupine termis paste. It was prepared by soaking the seeds in tap water for one week with changing the water daily, and then boiled in water for $2 \mathrm{~h}$, cooled and peeled. The peeled seeds were minced, and blended to get fine paste which then kept frozen until used. The composition of raw materials used is shown in Table 1.

Manufacturer of processed cheese analogue. The suitable amounts of raw materials (matured Ras cheese, soft cheese curd, lupine paste, butter, emulsifying salts and water) were added consecutively in laboratory processing Kettle (locally constructed) as mentioned by Awad [1996]. All blends were adjusted to contain $58 \%$ moisture, $50 \%$ fat $/ \mathrm{DM}$ and $2.5 \%$ emulsifying salts $(\mathrm{S} 9 \mathrm{~s}+\mathrm{No}, 1: 1)$. Lupine paste was added to the formula as a substitute of cheeses 
Awad R.A., Salama W.M., Farahat A.M., 2014. Effect of lupine as cheese base substitution on technological and nutritional properties of processed cheese analogue. Acta Sci. Pol., Technol. Aliment. 13(1), 55-64.

Table 1. Composition of raw materials used in the manufacture of processed cheese spread

\begin{tabular}{lccc}
\hline $\begin{array}{r}\text { Character } \\
\text { assessed }\end{array}$ & Ras cheese & $\begin{array}{c}\text { Soft cheese } \\
\text { curd }\end{array}$ & Lupine paste \\
\hline Moisture, \% & 47.46 & 77.15 & 69.72 \\
Fat, \% & 36.00 & 3.00 & 9 \\
Protein, \% & 26.78 & 10.75 & 38.00 \\
Ash, \% & 4.39 & 2.15 & 0.72 \\
pH value & 6.92 & 7.05 & 5.98 \\
\hline
\end{tabular}

Table 2. Formulations of different processed cheese analogue with lupine paste, $\mathrm{kg} / 100 \mathrm{~kg}$

\begin{tabular}{lccccc}
\hline \multirow{2}{*}{ Ingredients } & \multicolumn{5}{c}{ Treatments } \\
\cline { 2 - 6 } & control & $\mathrm{T}_{1}$ & $\mathrm{~T}_{2}$ & $\mathrm{~T}_{3}$ & $\mathrm{~T}_{4}$ \\
\hline Ras cheese & 30.20 & 20.20 & 15.20 & 8.80 & - \\
Soft curd & 54.30 & 39.70 & 29.70 & 18.20 & - \\
Lupine paste & - & 20.00 & 32.00 & 47.10 & 68.20 \\
Butter oil & 10.08 & 12.55 & 13.79 & 15.59 & 17.48 \\
Emulsifying & 2.5 & 2.5 & 2.5 & 2.5 & 2.5 \\
salts (S9s + & & & & & \\
No, 1:1) & & & & & \\
Water & 2.92 & 5.05 & 6.81 & 6.81 & 11.82 \\
Total & 100 & 100 & 100 & 100 & 100 \\
\hline
\end{tabular}

in ratios of $25,50,75$ and $100 \%$. The mixture was cooked for $10 \mathrm{~min}$ at $85-90^{\circ} \mathrm{C}$ using indirect steam at pressure $2-2.5 \mathrm{~kg} / \mathrm{cm}^{2}$. The mixture was hot filled into wide mouth glass jars and capped directly after filling. The resultant cheese analogue was analysed when manufactured and after 1, 2 and 3 months of storage in refrigerator $\left(5 \pm 2^{\circ} \mathrm{C}\right)$. The composition of all different formulations is shown in Table 2.

Experimental animals (in vivo analysis). Clinically healthy male albino rats aged three months and $180 \mathrm{~g} / \mathrm{rat}$ average body weight were used in the present study. Rats were purchased from the Experimental Animal House, Eyes Research Center, Giza, Egypt.
Rats were fed for one week before starting the experiment on basal diet then divided randomly into three groups each of 7 animals. The basal diet consisted of $15 \%$ protein as casein, $10 \%$ cellulose as fiber, $10 \%$ fat as corn oil, 5\% mixture of vitamins and salts and $60 \%$ carbohydrate as starch according to During et al. [2000]. The first group was fed for another more week on basal diet (negative control), while the $2^{\text {nd }}$ and $3^{\text {rd }}$ groups were fed on basal diet supplemented with $20 \%$ of control processed cheese without lupine (positive control) and cheese analogue supplemented with 75\% lupine paste respectively. The diet given to the $3^{\text {rd }}$ group continued for 4 weeks. All biological examinations were carried out in the initial and periodically to follow up the health parameters of experimental animals.

Chemical analysis. Samples of cheese analogues were tested for moisture, acidity and ash contents as mentioned in AOAC [1990]. Fat, total and soluble nitrogen contents were determined according to the method described in Ling [1963]. Total carbohydrates were calculated by differences as described by Ceirwyn [1995].

Physicochemical properties. Values of $\mathrm{pH}$ were measured using a digital $\mathrm{pH}$ meter (HANNA), with combined glass electrode (Electric Instruments Limited). Meltability of cheese analogue was tested as described by Aront et al. [1957]. The oil separation index of processed cheese analogues was determined according to Thomas [1973]. Firmness was measured using penetrometer (Kochler Co. Inc., USA) as mentioned by El-Shabrawy et al. [2002] and penetration depth was recorded in units of $0.1 \mathrm{~mm}$. The penetrometer reading is inversely related to firmness of cheese analogue.

Biological examination. The changes in body weight of albino rats were recorded weekly. Weight gains (which is the difference between final weight and initial weight), feed consumption (total food consumed during the period of experimental for each group) and feed conversion (feed consumption/weight gain) were calculated. Blood samples were obtained weekly from orbitial plexus of the eyes for all rats. The plasma was obtained from blood samples by centrifugation at $1500 \mathrm{rpm}$ for $15 \mathrm{~min}$ at an ambient temperature and plasma glucose level was determined according to Trinder [1969]. 
Awad R.A., Salama W.M., Farahat A.M., 2014. Effect of lupine as cheese base substitution on technological and nutritional properties of processed cheese analogue. Acta Sci. Pol., Technol. Aliment. 13(1), 55-64.

Histopathological examination. Autopsy samples were taken from the pancreas of the sacrificed rats according to the method of Banchroft et al. [1996]. Samples were fixed in $10 \%$ formalin saline solution for $10 \mathrm{~h}$, and then washed in tap water for 12 hours. Serial alcohol concentrations were used for dehydration of the tissue samples; tissue specimens were cleared in xylene and embedded in paraffin. The paraffin blocks were sectioned at three micron thickness by sledge microtome. The obtained tissue sections were collected on the glass slides and stained by hematoxylin and eosin stain for light microscopy.

Sensory evaluation. Samples of cheese analogues were sensory scored by 8-10 panelists according to the scheme of Meyer [1973] for outer appearance (20 points), body and texture (40 points) and aroma and flavor (40 points). The course of scoring for each sample was repeated three times and all collected data were statistically analyzed according to SAS Institute (1990) using liner Model (GLM). Duncan's multiple range was used to separate among means of three replicates at $p \leq 0.05$.

\section{RESULTS AND DISCUSSION}

\section{Chemical composition of processed cheese analogue}

Effect of adding lupine paste on the chemical composition of processed cheese treatment analogues is presented in Table 3. Total solid and fat contents in all processed treatments were in narrow range. This was expected since all the experiments were adjusted in the formula before cooking process. Total protein and ash contents were the lowest in control treatment while adding sweet lupine paste in different ratios increased proportionally the values of total protein and ash in treatments. The higher total protein and ash contents in cheese analogue treatments with lupine paste as a substitution of raw cheese are related to the higher values of protein and ash in lupine compared to soft curd or Ras cheese used in base formula in Table 1. Carbohydrate (as lactose) content was the highest (5.05\%) in control treatment of processed cheese. Among analogue treatments, processed cheese with $100 \%$ substitution of raw cheese with lupine $\left(\mathrm{T}_{4}\right)$ had the lowest $(2.25 \%)$ carbohydrate content, while $\mathrm{T}_{1}$ showed the highest one (3.71\%).
Table 3. Chemical composition (\%) of fresh processed cheese analogues as affected by different substitution levels of raw cheese with lupine paste

\begin{tabular}{lccccc}
\hline \multirow{2}{*}{$\begin{array}{c}\text { Character } \\
\text { assessed }\end{array}$} & \multicolumn{5}{c}{ Treatments } \\
\cline { 2 - 6 } & control & \multicolumn{1}{c}{$\mathrm{T}_{1}$} & \multicolumn{1}{c}{$\mathrm{T}_{2}$} & \multicolumn{1}{c}{$\mathrm{T}_{3}$} & $\mathrm{~T}_{4}$ \\
\hline Total solids & 41.89 & 42.70 & 42.62 & 42.36 & 42.05 \\
Fat & 20.00 & 21.50 & 21.50 & 21.00 & 21.00 \\
Protein & 13.60 & 14.12 & 14.19 & 14.66 & 14.88 \\
Ash & 3.20 & 3.37 & 3.66 & 3.81 & 3.92 \\
Carbohydrate* & 5.05 & 3.71 & 3.27 & 2.89 & 2.25 \\
\hline
\end{tabular}

Treatments $\mathrm{T}_{1}, \mathrm{~T}_{2}, \mathrm{~T}_{3}, \mathrm{~T}_{4}$ with $25,50,75$ and $100 \%$ lupine paste substitution of cheese base respectively.

*Calculated by difference.

\section{Values of pH, acidity and SN in cheese analogue}

Replacing cheese base in the blend with lupine paste resulted in lowering $\mathrm{pH}$ values of processed cheese analogue. This could be due to the low $\mathrm{pH}$ of lupine used in the formula (5.98) compared to 6.92 or 7.05 for Ras or soft cheese respectively. Among all treatments are shown in Figure 1 control processed cheese showed highest $\mathrm{pH}$ value. Treatments supplemented with lupine paste showed slightly lower $\mathrm{pH}$. The $\mathrm{pH}$ indicated a slight and gradually decreases during storage of all treatments. The decrease in $\mathrm{pH}$ during storage could be related to the hydrolysis occurred in emulsifying salts and their interaction with proteins. These findings are in agreement with Awad and Salama [2010 a, b]. Changes of acidity had an opposite trend to that occurred in $\mathrm{pH}$ being higher in treatments of lupine paste with slight proportional increase during storage period. Similar observation was recorded by Awad [2003]. Incorporating lupine paste in the base formula increased the soluble nitrogen $(\mathrm{SN})$ content compared to control (Fig. 1). During storage, the value of SN increased in all treatments including control. The changes in SN during storage could be the result of enzymatic activity of resistant proteinases present in the product. It could be also due to the hydrolysis of polyphosphate in emulsifying salts which caused more solubilization of proteins. These results are in agreement with those reported by Awad [2003] and Awad and Salama [2010 a, b]. 
Awad R.A., Salama W.M., Farahat A.M., 2014. Effect of lupine as cheese base substitution on technological and nutritional properties of processed cheese analogue. Acta Sci. Pol., Technol. Aliment. 13(1), 55-64.
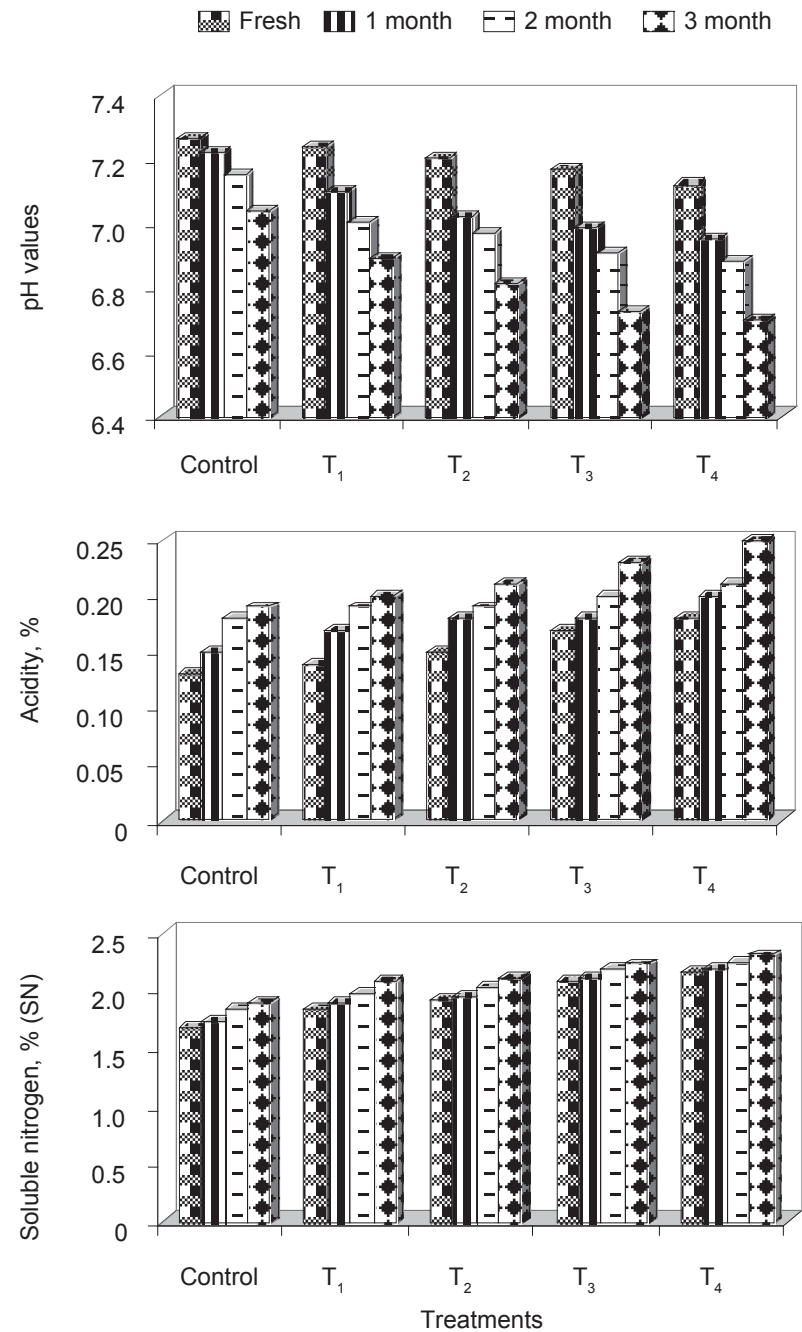

Fig. 1. Changes in $\mathrm{pH}$ values, acidity and soluble nitrogen $(\%)$ of fresh and stored processed cheese analogue as affected by substitution levels of lupine paste

\section{Physicochemical properties}

Meltability values of processed cheese analogues were affected by the substitution of raw cheese with lupine paste is shown in Table 4. Adding lupine paste in base formula decreased the cheese analogue meltability compared to control. The results indicated that treatment with $25 \%$ lupine $\left(\mathrm{T}_{1}\right)$ had the highest melting properties compared to other treatments including control cheese. The melting value decreased with increasing the percentage of added lupine being lowest in $\mathrm{T}_{4}$ with $100 \%$ substitution. The lower meltability of cheese treatments containing lupine may be due to its high casein and total protein contents. During storage the melting values increased in all treatments including control. The changes in meltability during storage could be related to the protein degradation that occurred in the cheese, which led to high SN and increase of cheese flow. These findings are in agreement with those of Awad [2003] and Awad and Salama [2010 b].

Firmness of cheese analogue. The results in Table 4 indicate that the highest penetration value was observed in control treatment. On the other hand, analogue treatments with lupine paste showed lower penetration which means firmer product than control treatment. It is well known that penetrometer reading is inversely related to the cheese firmness. The lower penetration value and so higher firmness in cheese analogue containing lupine paste could be due to the higher total protein content in the blend. These data agree with Tamime et al. [1990] who stated that the firmness of processed cheese was increased by the addition of soy, whey or egg proteins. In stored processed cheese samples, the penetration values decreased

Table 4. Meltability and penetration values of processed cheese analogue as affected by using different levels of lupine paste, fresh and stored

\begin{tabular}{lccccc}
\hline \multirow{2}{*}{$\begin{array}{c}\text { Storage period } \\
\text { month }\end{array}$} & \multicolumn{5}{c}{ Treatments } \\
\cline { 2 - 6 } Meltability, mm & control & $\mathrm{T}_{1}$ & $\mathrm{~T}_{2}$ & $\mathrm{~T}_{3}$ & $\mathrm{~T}_{4}$ \\
\hline Fresh & 45 & 58 & 32 & 25 & 5 \\
1 & 53 & 62 & 45 & 34 & 7 \\
2 & 65 & 80 & 48 & 41 & 10 \\
3 & 75 & 84 & 54 & 48 & 11 \\
Penetration, mm & & & & & \\
Fresh & 31.8 & 21.6 & 14.3 & 13.6 & 10.5 \\
1 & 30.5 & 20.8 & 12.5 & 11.3 & 9.4 \\
2 & 28.2 & 20.0 & 10.3 & 10.9 & 8.1 \\
3 & 25.8 & 18.3 & 8.5 & 7.8 & 5.6 \\
\hline
\end{tabular}

Treatments $\mathrm{T}_{1}, \mathrm{~T}_{2}, \mathrm{~T}_{3}, \mathrm{~T}_{4}$ with $25,50,75$ and $100 \%$ lupine paste substitution of cheese base respectively. 
Awad R.A., Salama W.M., Farahat A.M., 2014. Effect of lupine as cheese base substitution on technological and nutritional properties of processed cheese analogue. Acta Sci. Pol., Technol. Aliment. 13(1), 55-64.

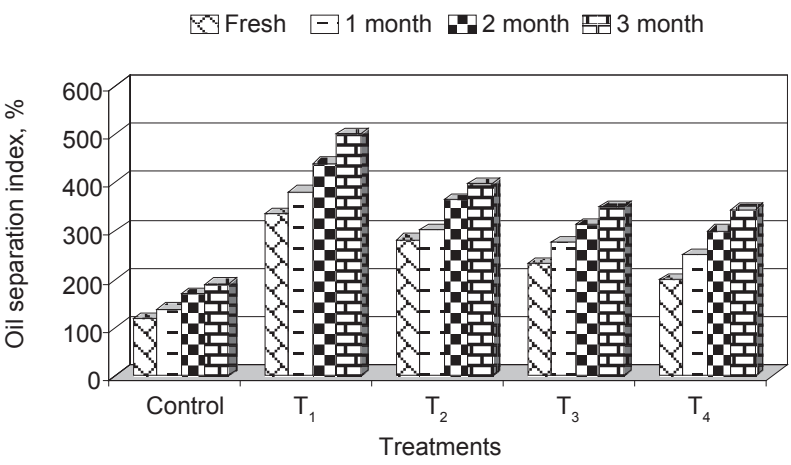

Fig. 2. Oil separation index of processed cheese analogues as affected by substitution level of lupine paste, fresh and during storage period

with prolonging the storage period, i.e., the firmness increased. This could be attributed to the nature of protein in the formula with the affinity to low and degradation changes in the product during storage especially the low $\mathrm{pH}$ value. The data agree with Awad [2003] and Awad and Salama [2010 a, b].

Oil separation index. The data in Figure 2 indicate that control cheese had the lowest fat separation index compared to samples containing lupine paste either when fresh or during storage. Processed cheese analogue with $25 \%$ lupine $\left(\mathrm{T}_{1}\right)$ had the highest oil separation index, while $\mathrm{T}_{4}$ showed the lowest one. The fat separation decreased with increasing the added percentage of lupine in the formula which could be mainly attributed to the nature of lupine protein that may affect the emulsification degree of the product. The oil index value depends on the state of fat and protein in resultant processed cheese emulsion which can be affected by type and amount of raw materials in the base formula, $\mathrm{pH}$ value, cooking time and temperature. The oil index of processed treatments including control was affected by storage period. Storage of processed samples increased the free oil in the product. This may be due to the corresponding changes in $\mathrm{pH}$ value and $\mathrm{SN}$ content during storage. These findings agree with Awad [2003], Awad and Salama [2010 a, b].

Texture profile of processed cheese analogue. The textural properties of processed cheese analogue samples are shown in Table 5. From the obtained results it could be seen that, addition of lupine paste in the blend increased the hardness of cheese treatments
Table 5. Texture profile analysis of fresh and stored processed cheese analogues as affected by substitution levels of lupine paste

\begin{tabular}{lccccc}
\hline \multirow{2}{*}{ Parameters } & \multicolumn{5}{c}{ Treatments } \\
\cline { 2 - 6 } & control & $\mathrm{T}_{1}$ & $\mathrm{~T}_{2}$ & $\mathrm{~T}_{3}$ & $\mathrm{~T}_{4}$ \\
\hline Fresh & & & & & \\
Firmness, N* & 5.901 & 6.523 & 8.271 & 9.680 & 10.571 \\
Cohesiveness, & 0.294 & 0.155 & 0.106 & 0.047 & 0.003 \\
g/cm & & & & & \\
Gumminess, N & 0.699 & 0.923 & 1.558 & 0.924 & 0.095 \\
Springiness, mm & 0.283 & 0.266 & 0.128 & 0.060 & 0.020 \\
Chewiness, N & 0.654 & 0.497 & 0.301 & 0.094 & 0.004 \\
3 month & & & & & \\
Firmness, N & 7.26 & 8.69 & 11.38 & 13.14 & 15.69 \\
Cohesiveness, & 0.392 & 0.196 & 0.183 & 0.164 & 0.145 \\
g/cm & & & & & \\
Gumminess, N & 0.846 & 0.947 & 2.086 & 0.280 & 2.149 \\
Springiness, mm & 0.458 & 0.240 & 0.215 & 0.154 & 0.161 \\
Chewiness, N & 1.306 & 0.699 & 0.447 & 0.332 & 0.367 \\
\hline
\end{tabular}

Treatments $\mathrm{T}_{1}, \mathrm{~T}_{2}, \mathrm{~T}_{3}, \mathrm{~T}_{4}$ with $25,50,75$ and $100 \%$ lupine paste substitution of cheese base respectively.

$* \mathrm{~N}-$ newton.

compared to control. The increase in hardness values were proportional to the ratio added of lupine paste in formula of processed cheese. Control cheese had low protein content, which is mainly casein, while treatments contained quantities of lupine protein and lower content of casein. This may explain the differences in textural parameters of cheese due to the difference in the properties of occurring proteins [Fox et al. 2000]. Storage of cheese increased to more extent the hardness. This is may be due to the less availability of water during storage as well as loss of texture integrity generated by proteolysis activities. These observations agree with the results of Awad et al. [2006]. The results in Table 5 also, indicated that the cohesiveness of cheese samples decreased as lupine paste ratio increased in the blend. After 90 days of storage, the cohesiveness value greatly increased in all cheese, and control treatment showed the highest 
value. Gumminess showed the maximum values in fresh processed cheese analogue with 50\% lupine and in the stored cheese with $75 \%$ lupine. Gumminess values increased during storage of all treatments including control with storage. These data agree with the results of El-Baz et al. [2011]. Springiness values were higher in control cheese analogue than those of

Table 6. Sensory evaluation score of analogue type processed cheese supplemented with different ratios of lupine paste during cold storage

\begin{tabular}{lccccc}
\hline \multirow{1}{*}{ Sensory attributes } & \multicolumn{5}{c}{ Treatments } \\
\cline { 2 - 6 } & control & $\mathrm{T}_{1}$ & $\mathrm{~T}_{2}$ & $\mathrm{~T}_{3}$ & $\mathrm{~T}_{4}$ \\
\hline Fresh & & & & & \\
Outer appearance (20) & 19 & 18 & 18 & 16 & 16 \\
Body and texture (40) & 38 & 37 & 36 & 34 & 32 \\
Flavor (40) & 38 & 38 & 36 & 35 & 33 \\
Total score (100) & $95^{\mathrm{a}}$ & $93^{\mathrm{a}}$ & $90^{\mathrm{ab}}$ & $85^{\mathrm{bc}}$ & $81^{\mathrm{c}}$ \\
1 month & & & & & \\
Outer appearance (20) & 18 & 17 & 17 & 16 & 15 \\
Body and texture (40) & 37 & 36 & 34 & 32 & 30 \\
Flavor (40) & 37 & 37 & 36 & 35 & 32 \\
Total score (100) & $92^{\mathrm{a}}$ & $90^{\mathrm{a}}$ & $87^{\mathrm{ab}}$ & $83^{\mathrm{bc}}$ & $77^{\mathrm{c}}$ \\
2 month & & & & & \\
Outer appearance (20) & 18 & 17 & 16 & 15 & 14 \\
Body and texture (40) & 36 & 34 & 32 & 31 & 29 \\
Flavor (40) & 36 & 35 & 34 & 33 & 31 \\
Total score (100) & $90^{\mathrm{a}}$ & $86^{\mathrm{ab}}$ & $82^{\mathrm{bc}}$ & $79^{\mathrm{cd}}$ & $74^{\mathrm{d}}$ \\
3 month & & & & & \\
Outer appearance (20) & 17 & 16 & 15 & 15 & 14 \\
Body and texture (40) & 36 & 32 & 31 & 29 & 27 \\
Flavor (40) & 36 & 35 & 32 & 31 & 31 \\
Total score (100) & $89^{\mathrm{a}}$ & $83^{\mathrm{ab}}$ & $78^{\mathrm{bc}}$ & $75^{\mathrm{cd}}$ & $72^{\mathrm{d}}$ \\
\hline & & & & & \\
\hline & & & & & \\
\hline & & & & & \\
\hline
\end{tabular}

Treatments $\mathrm{T}_{1}, \mathrm{~T}_{2}, \mathrm{~T}_{3}, \mathrm{~T}_{4}$ with $25,50,75$ and $100 \%$ lupine paste substitution of cheese base respectively.

Means with the same letter among treatments are not significantly different $(\mathrm{P} \leq 0.05)$. other treatments with lupine paste. However, Springiness greatly reduced with increasing the added ratio of lupine in the formula of cheese. During storage, the cheese analogue became springier and springiness value was increased in all analogues including control. Adding lupine paste in cheese analogues formula decreased markedly the cheese chewiness. After 3 month of storage, chewiness greatly increased in all cheese samples including control.

\section{Sensory evaluation}

The average score for sensory properties is represented in Table 6 . The outer appearance of treatments with lupine as a substitution of cheese up to $25 \%$ was most preferable. The appearance became less acceptable with increasing the added ratio of lupine in the base blend. Body and texture of control cheese was much better than treated cheeses. The data also, indicated that addition of lupine in the blend led to less acceptable product. All obtained processed cheese analogue were acceptable but the most acceptable blends of cheese analogue were produced with adding $25 \%$ of cheese base as lupine paste which ranked slightly higher total scores than that of other lupine treatments. Statistical analysis among all treatments indicated that the one with $25 \%$ lupine was not significantly differed than control. The sensory quality attributes of all treatments including the control decreased during storage. These data agree with the findings of Awad and Salama [2010 a, b] who mentioned that the acceptability of processed cheese decreased with extending the storage period.

\section{In vivo biological examinations of processed cheese analogue}

Feed consumption, weight gain and feed conversion ratio of albino rats as affected by feeding on diet containing processed cheese containing lupine paste are presented in Table 7 . The data cleared that treatment group consumed higher level of diet through the treating period. This could be a reflection of better health of rat in treatment group than that in positive or negative group. Therefore the weight gained in treatment group fed on processed cheese fortified with lupine paste was higher than positive or negative group. These results are in agreement with Ghazal [2003]. Feed conversion ratio (FCR) which is the ratio 
Awad R.A., Salama W.M., Farahat A.M., 2014. Effect of lupine as cheese base substitution on technological and nutritional properties of processed cheese analogue. Acta Sci. Pol., Technol. Aliment. 13(1), 55-64.

Table 7. Feed consumption, weight gain and feed conversion ratio of albino rats feed on processed cheese with $75 \%$ lupine paste substitution of cheese base

\begin{tabular}{lccc}
\hline \multirow{2}{*}{ Character assessed } & \multicolumn{3}{c}{ Group } \\
\cline { 2 - 4 } & positive & negative & treatment \\
\hline Feed consumption, g & 861 & 1293 & 1314 \\
Weight gain, g & -21.25 & 35.5 & 79.75 \\
Feed conversion ratio, FCR & 40.52 & 36.42 & 16.48 \\
\hline
\end{tabular}

between the feed consumption to the weight gained through the experimental period was lower in rat group fed on lupine processed than that of positive or negative group. Therefore, including lupine in the diet of rat resulted in a better health with higher efficiency to convert the consumed diet to weight gained in experimental animals.

\section{Effect of feeding a diet containing lupine paste on blood glucose of rats}

Blood glucose of albino rats as affected by feeding a diet containing cheese supplemented with $75 \%$ lupine paste is presented in Table 8 . The data indicated that the blood glucose levels of rats were affected by feeding on a diet enriched with lupine paste. The blood glucose level in positive control group was significantly higher than that of experimental group during the feeding period. At the end of feeding period, the treatment group which fed on lupine enriched diet had the lowest levels of blood glucose. The results are in agreement with those obtained by Abd Elaziz [2011]. Several previous studies were undertaken to understand how some plants which have action on the

Table 8. Blood glucose $(\mathrm{mg} / \mathrm{dl})$ of albino rats as affect by feeding on processed cheese spreads supplemented with $75 \%$ lupine paste

\begin{tabular}{cccc}
\hline \multirow{2}{*}{$\begin{array}{c}\text { Feeding period } \\
\text { week }\end{array}$} & \multicolumn{3}{c}{ Group } \\
\cline { 2 - 4 } & negative & positive & treatment \\
\hline Zero & 381 & 392 & 388 \\
2 & 389 & 398 & 209 \\
4 & 421 & 406 & 117 \\
\hline
\end{tabular}

blood glucose. These plants may act on blood glucose through different mechanisms, some of them may have insulin like substances [Collier et al. 1987], some may increase insulin output or inhibit the intestinal absorption of glucose or to the facilitation of metabolites in insulin dependent processes [Jia et al. 2003]. Other may increase beta cells in the pancreas by activating regeneration of these cells [Shanmugasundaram et al. 1990].

\section{Histopathological examinations}

Histological examinations of pancreas from rats fed on different diets are shown in Figure 3. Rats fed on balanced diet containing control processed cheese (Positive group) showed atrophy, hypertrophy and congestion of blood vessels and necrosis in islets of langerhans. Feeding rats on balanced diet containing processed cheese enriched with lupine paste showed marked improvements in islets structure after 30 days compared to rats fed a basil diet (negative group). Our results are coincided with Hall et al. [2005] who attributed the hypoglycemic effect of lupine termis to the higher protein content that stimulating a higher insulin response. It could be also attributed to the actions of various phytochemicals and dietary fiber found in lupine termis. Mohamed and El-Shorbagi [1993] and Knecht et al. [2006] found that lupine termis contain saponin, alkaloids and Tannin. Saponins have hypoglycemic activity which may be due to the inhibition of liver glycogenesis or glycolysis and that lead to a pronounced hypoglycemic effect.

\section{CONCLUSION}

Adding lupine paste in cheese analogue formula decreased the meltability, penetration and fat separation in the processed product. Cohesiveness and springiness values were decreased with adding lupine paste to analogue formula. All obtained processed cheese analogue were acceptable but the most acceptable blend was produced with substituting $25 \%$ of cheese base as lupine paste. Incorporating lupine in the diet of rat resulted in a better health with higher efficiency to convert the consumed diet to weight gained in experimental animals and treatment group which fed on lupine enriched diet showed the lowest levels of blood glucose. Marked improvements in islets structure after 
Awad R.A., Salama W.M., Farahat A.M., 2014. Effect of lupine as cheese base substitution on technological and nutritional properties of processed cheese analogue. Acta Sci. Pol., Technol. Aliment. 13(1), 55-64.

A

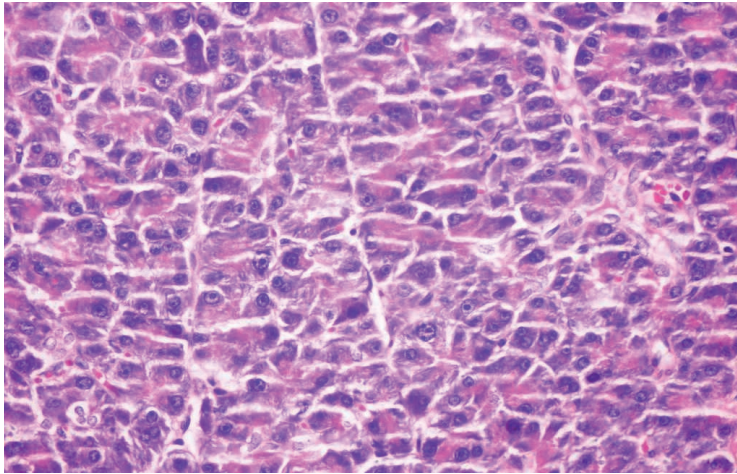

B

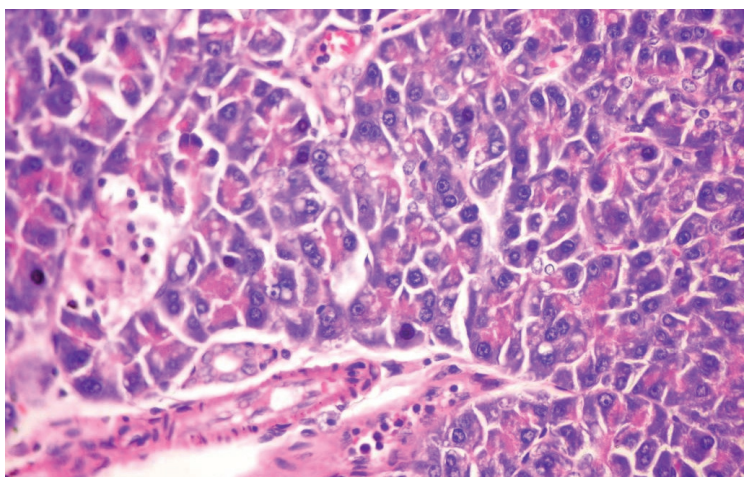

C

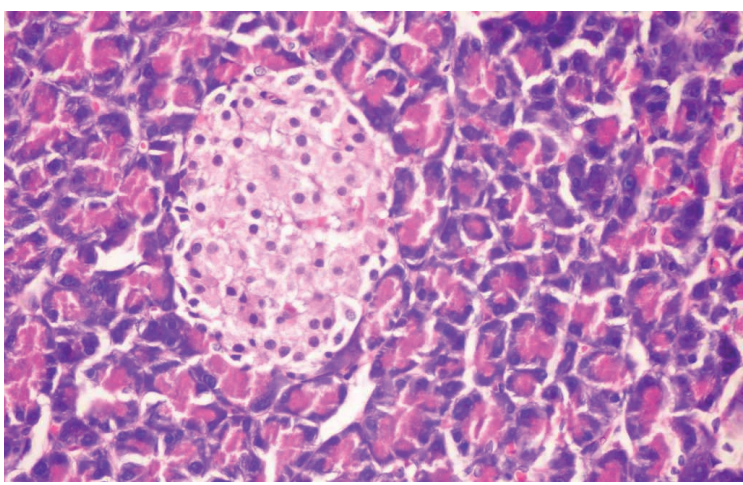

Fig. 3. Pancreas of rat from: $\mathrm{A}$ - negative group showing normal pancreatic acini, B - positive group showing vacuolations of epithelial lining pancreatic acini and necrosis of islets in langerhans, $\mathrm{C}$ - treatment group showing no histopathological changes

30 days compared to rats fed a basil diet was noticed in rats fed on balanced diet containing processed cheese enriched with lupine paste. New processed cheese analogue can be successfully made using lupine paste as source of protein which improve nutritive and health value of resultant.

\section{REFERENCES}

Abd Elaziz E.A., 2011. Pathological and biochemical studies on the effect of Trigonella foenum - Graecum and Lupinus termis in alloxan induced diabetic rats. World Appl. Sci. J. 12, 1839-1850.

AOAC, 1990. Official methods of analysis. Association of Official Analytical Chemistry Washington.

Arnot D.R., Morris H.A., Combs W.B., 1957. Effect of certian chemical factors on the melting quality of process cheese. J. Dairy Sci. 40, 957.

Awad R.A., 1996. Studies on emulsifying salt mixture for processed cheese. Ph.D. Thesis. Facult. Agric. Ain Shams Univ. Cairo.

Awad R.A., 2003. Impact of potato puree as a cheese base replacement in the manufacture of processed cheese. Egypt. J. Dairy Sci. 2, 375-387.

Awad R.A., Salama W.M., 2010 a. Effect of adding whole fresh or boiled egg on the quality of processed cheese spread Egypt. J. Dairy Sci. 38, 105-113.

Awad R.A., Salama W.M., 2010 b. Development of a novel processed cheese product containing fermented barley. Egypt. J. Dairy Sci. 38, 95-103.

Awad S.A., Aisha M.A., El-Soda M.A., 2006. Ripened curd cheese slurries in the manufacture of processed cheese. Alex. J. Food Sci. Tech. 3, 43.

Banchroft J., Stevens A., Tumer D., 1996. Theory and practice of histological techniques. Churchill Livingstone New York.

Caric M., Kalab M., 1993. Processed cheese products. In: Cheese: Chemistry, physics and microbiology. Vol. 2. Ed. P.F. Fox. Chapman and Hall London, UK.

Ceirwyn S.J., 1995. Analytical chemistry of foods. Part 1. Chapman and Hall London.

Collier C.C.A., Steedman D.J., Patrick A.W., Nimmo G.R., Matthews D.M., MacIntyre C.C., Little K., Clarke B.F., 1987. Comparison of intravenous glucagon and dextrose in treatment of severe hypoglycaemia in an accident and emergency department. Diabetes Care 10, 712-751.

During A., Combe N., Mazette S., Entressangles B., 2000. Effect on cholesterol balance and LDL cholesterol in the rat of a soft - ripened cheese containing vegetable oils. J. Am. Coll. Nutr. 19, 4, 458-466.

El-Baz A.M., Ibrahim E.M., Mehanna N.M., 2011. Impact of using exopolysaccharides (EPS) producing cultures on improving quality of Ras cheese made from pasteurized milk. Egypt. J. Dairy Sci. 39, 127.

El-Neshawy A.A., Farahat S.M., Wahbah H.A., 1988. Production of processed cheese food enriched with vegetable and whey proteins. Food Chem. 4, 245-255. 
Awad R.A., Salama W.M., Farahat A.M., 2014. Effect of lupine as cheese base substitution on technological and nutritional properties of processed cheese analogue. Acta Sci. Pol., Technol. Aliment. 13(1), 55-64.

El-Shabrawy S.A., Awad R.A., Saad S.A., 2002. Manufacture and properties of flavoured processed cheese spread with different fruit flavour. J. Ann. Agric. Sci. AinShams Univ. Cairo 10, 641.

Erickson J.P., 1985. Lupins show potential as protein source for livestock. Feedstuffs 57, 22-24.

Fox P.F., Guinee T.P., Cogan T.M., McSweeney P.L.H., 2000. Cheese rheology and texture. In: Fundamentals of cheese science. Aspen Publ. Gaithersburg, 305-333.

Gaultier F., Foucault-Bertaud A., Lamy E., Ejeil A.L., Dridi S.M., Piccardi N., 2003. Effects of a vegetable extract from Lupinus albus (LU105) on the production of matrix metalloproteinase (MMP1, MMP2, MMP9) and tissue inhibitor of metalloproteinases (TIMP1, TIMP2) by human gingival fibroblasts in culture. Clin. Oral Invest. 7 (4), 198-205.

Ghazal G.A.I., 2003. Biological and nutritional values of tempeh like-products made from lupine and pea. Ann. Agric. Sci. Moshtohor 41, 2, 739-749.

Hall R.S., Thomas S.J., Jahnson S.K., 2005. Australian sweet lupin flour addition reduces the glycemic index of a white bread breakfast without affecting palatability in the healthy human volunteers. Asia Pac. J. Clin. Nutr. 14 (1), 91-97.

Hofi A.A., Youssef E.H., Ghoneim M.A., Tawab G.A., 1970. Ripening changes in Cephalotyre 'Ras' cheese manufacture from raw and pasteurized milk with special referances to flavour. J. Dairy Sci. 53, 1207.

Hussein G.A., Fathi F.A., Mohamed A.G., 2005. Quality and acceptability of processed cheese spreads made from total milk proteinate and casein co-precepitate. Egypt. J. Dairy Sci. 33, 261-277.

James L.F., Panter K.E., Gaffield W., Molyneux R.J., 2004. Biomedical applications of poisonous plant research. J. Agric. Food Chem. 52, 3211-3230.

Jia W., Gao W.Y., Xiao P.G., 2003. Antidiabetic drugs of plants origin used in china: Comparison, pharmacology and hypoglycemic mechanism. Zhongguo Zhong Yaa Za Zhi 28, 108-113.

Knecht K.T., Guyen H.N., Auker A.D., Kinder H.D., 2006. Effects of extracts of lupine seed on blood glucose levels in glucose resistant mice. J. Herbal Pharmacoth. 6 (3-4), 89-104.

Ling E.R., 1963. A text book of dairy chemistry. Vol. 2. Practical. Chapman and Hall London.
Martínez-Villaluenga C., Sironi E., Vidal-Valverde C., Duranti M., 2006. Effect of oligosaccharide removing procedure on the protein profiles of lupin seeds. Eur. Food Res. Techn. 223, 691-696.

Meyer A., 1973. Processed cheese manufacture. Food Trade London, UK.

Mohamed M.H., El-Shorbagi A.N.A., 1993. ( \pm )-Termisine, anovel lupine alkaloid from the seeds of Lupinus termis. J. Nat. Prod. 56, 1999-2002.

Oomah B.D., Tiger N., Olson M., Balasubramanian P., 2006. Phenolics and antioxidative activities in narrow-leafe lupine (Lupinus angustifolius L.). Plant Foods Hum. Nutr. 61, 91-97.

SAS, 1990. SAS User's Guide/STAT ver. 6.04. SAS Inst. Cary, NG.

Shanmugasundaram E.R, Rajeswari G., Baskaran K., 1990. Use of Gymnema sylvestre leaf extract in the control of blood glucose in insulin-dependent diabetes mellitus. J. Ethnopharmacol. 30, 281-294.

Smart V., Foster P.S., Rothenberg M.E., Higgins T.J., Hogan S.P., 2003. A plant-based allergy vaccine ssuppresses experimental asthma via an IFN-gamma and CD4 + CD45R Blow T cell-dependent mechanism. J. Immunol. 171 (4), 2116-2120.

Stoon A.E., 2002. The top 10 functional food trends. The next generation. Food Technol. 56, 32-37.

Tackholm V., 1974. Students' flora of Egypt. Cairo Univ. Cairo.

Tamime A.Y., Kalab M., Davies G., Youns M.F., 1990. Microstructure and firmness of processed cheese manufactured from Cheddar cheese and skim milk powder cheese base. Food Microstruct. 9, 23.

Thomas M.A., 1973. The use of a hard milk fat fraction in processed cheese. Aust. J. Dairy Technol. 28, 77-80.

Torres A., Frias J., Vidal-Valverde C., 2005. Changes in chemical composition of lupin seeds (Lupinus angustifolius) after a-galactoside extraction. J. Sci. Food Agri. 85, 2468-2474.

Trinder P.L., 1969. Enzymatic determination of glycogen and lipids from muscle. Anal. Biochem. 6, 24-27.

Wäsche A., Müller K., Knauf U., 2001. New processing of lupin protein isolates and functional properties. Nahrung 45, 393-395.

Accepted for print - Zaakceptowano do druku: 1.10.2013

Received - Przyjęto: 27.05.2013

For citation - Do cytowania

Awad R.A., Salama W.M., Farahat A.M., 2014. Effect of lupine as cheese base substitution on technological and nutritional properties of processed cheese analogue. Acta Sci. Pol., Technol. Aliment. 13(1), 55-64. 